\title{
EMPIRICAL ANALYSIS OF SAVINGS AND INVESTMENTS RELATION IN TURKEY: COINTEGRATION TEST WITH STRUCTURAL BREAKS APPROACH
}

\author{
DOI: 10.17261/Pressacademia.2017.439
}

JEFA- V.4-ISS.2-2017(4)-p.106-111

\section{Izzet Tasar}

Firat University, Faculty of Economics and Administrative Sciences, Department of Economics, Elazig, Turkey. itasar@firat.edu.tr

\section{To cite this document}

Tasar, I. (2017). Empirical analysis of savings and investments relation in Turkey: cointegration test with structural breaks approach. Journal of Economics, Finance and Accounting (JEFA), V.4, Iss.2, p.106-111.

Permemant link to this document: $h$ ttp://doi.org/10.17261/Pressacademia.2017.439

Copyright: Published by PressAcademia and limited licenced re-use rights only.

\begin{abstract}
Purpose- The main aims of the economic growth policies implemented by governments are to reach high and sustainable economic growth rates. In this regard, to define the relation between economic growth and national savings is quite impotant. Savings are very important in terms of economic growth that makes it an important issue in order to achieve economy policy targets.

Methodology- In this study, the relation between savings rates and investment rates will be investigated in the context of Feldstein Horioka (1980) puzzle for the Turkish economy for the period from 1980 to 2015.

Findings- Empirical findings show that variables have unit roots. Results obtained from Bai - Perron (2003) co-integration test which taking structural breaks into considiration show that there is a structural break in 1999 and the time span is taken into two sub-period. According to test results, the investigated relation between investments and savings is weak in the first period (1980 - 1998), while it is stronger in the second period starts from 1999 till 2015.

Conclusion- Investment rates are above the savings rates in the entire analysis period. This situation reveals as one of the main reason of current account deficit in Turkish economy.
\end{abstract}

Keywords: Savings, investments, structural breaks, co-integration, economic growth.

JEL Codes: E21, E22, F43,

\section{INTRODUCTION}

According to many economic schools, investments are the main source of economic growth. Many governments struggle with the economic situations in order to reach high rates of investment. In the theory, the investments in growth models linked with savings. When the national savings are inefficient, governments mostly increase the interest rates in order to find foreign capital to finance the investments in the local economy. That makes it very crucial the domestic savings and the foreign savings ratio in the economy. Turkish economy, especially after 1989 integrated the international markets via regulations that encourages liberalization. With the liberalization in the capital flows, the investments started to be financed by foreign sources. That rises few questions that, and this analysis will focus on answers to that questions; For investments in Turkish economy what is the rate of foreign capital? After the liberalization in the capital markets, does Turkey attract enough foreign capital? Do investments and domestic savings influence each other within the framework of structural breaks?

The rest of the paper is organized as follows. The next section is devoted to summarize the existing literature investigating the Feldstein-Horioka (1980) puzzle. The second section, econometric methodology and the data are introduced. In the section three, empirical results are presented. Empirical findings are summarized and concluded in the last section. 


\section{THEORETICAL BACKGROUND AND LITERATURE REVIEW}

Liteature has lots of examples that tries to define the relation between savings and investments. It is accepted that the milestone of all that arguments is the Feldstein-Horioka (1980) puzzle. Feldstein and Horioka (1980) investigated the investment saving relation in 16 different countries for the period from 1960 to 1974 . Their model is;

$$
\left(\frac{I}{Y}\right)=\beta_{0}+\beta_{1}\left(\frac{S}{Y}\right)+\varepsilon
$$

$\beta_{1}$ coefficient presents the foreign caiptal movement ratio. Feldstein and Horioka (1980) assume the coefficient as one, $\left(\beta_{1}=1\right)$ in the close economies due to the fact that there is no capital movement. Their second assumption is, that coefficient will decrease in the growth economies. The results of their analysis are a paradox. The 16 developed countries that they used in their analysis has a ratio between 0.85-0.95, and that is quite high compared to the expectations. According to Feldstein and Horioka (1980) even in the developed countries, the investments are financed via domestic savings. Feldstein and Horioka (1980) paradox empirically questioned many times, some of them hired times series analysis, some others preferred panel data analysis. Most of those studies aim to explain $\beta_{1}$ coefficient in the model due to the fact that it is a sign of the capital movement ratio. Feldstein (1983), Penati and Dooley (1984), Obsfeld (1995) Bayoumi (1990) and Wong (1990) supports Feldstein and Horioka (1980) paradox in the developed countries. Another finding is, the developing countries has smaller ratios. Ho (2002) employed FMOLS and DOLS method and applied his model on OECD countries for the period 1961-1997. FMOLS test results found out he coefficient as 0.84 and in DOLS method the result was 0.47, Blanchard and Giavazzi (2002) 1975-2001 again for OECD countries but in a different period tested the paradox via OLS method. The results were 0.58 for OECD countries and 0.41 for EU countries. Giannone and Lenza (2004) also tested the paradox for OECD countries and found out very low ratio for the coefficient. For the period 1970-1999 for 24 OECD countries the FAPR method offered $0.23-0.53$ for $\beta_{1}$. Kollias et al. (2008) for the period starting from1962 to 2002 examined EU countries via ARDL method, the result was 0.148. Ketenci (2010) for OECD countries, within the period 19702008 hired OLS and the result was 0.211, for EU15; 0.081, for NAFTA; 0.344 and for G7; 0.728, Ayaydın and Baltacl (2012) investigated BRICS by hiring GMM method for the period 1990-2011 and the coefficient was 0.796. Lastly, Erataş et al. (2013) for 1980-2012 period for G7 with CCE method found the coefficient 0.41 .

Feldstein-Horioka (1980) puzzle is also implemented in Turkish economy in order to see if it is valid or not. Erden (2005) examined the period from 1963 to 1980 and separates the period into two. First period that the capital movements were limited is the period 1963-2002 and the second period of 1981-2002 when the capital movements were not limited investigated separately. As a result of the study, in the first period when the capital movements were limited, the savingsinvestment relationship was strong, whereas in the second period when the capital movements were not limited, the savings-investment relationship was weakened. Bolatoğlu (2005) analyzed for the 1970-2005 and stated that the relationship between savings and investments is weak because the financial and commercial openness of the Turkish economy is not in the same level compared to developed countries. Altıntaş and Taban (2011) suggested the conclusion that the relationship between savings and investments is weak due to the lack of integration of the Turkish economy with the international markets in their analysis for the period 1974-2007. Esen et al. (2012) for the 1975-2009 period, offers the validity of Feldstein-Horioka (1980) puzzle. Another important find out of the study is, the increase in the short-term capital movements results the savings and investments relation to be weaker.

\section{EMPIRICAL ANALYSIS}

In this study, the validity of the Feldstein-Horioka (1980) hypothesis was examined in the Turkish economy for the period 1980-2015. For this purpose, the ratio of saving and investment to gross domestic product are hired as variables. In the scope of the analysis, first the correlations between variables are defined and descriptive statistics are given. Unit root test, developed by Dickey-Fuller (1981), was conducted to examine whether variables are exposed to economic shocks or not. Traditional co-integration tests do not reveal situations where structural breaks exists, traditional tests considers the whole period. The co-integration test developed by Bai-Perron (2003) considers the structural breaks so it will reveal both structural break dates and the co-integration relations for each period. 
Graph 1 : Saving Ratio

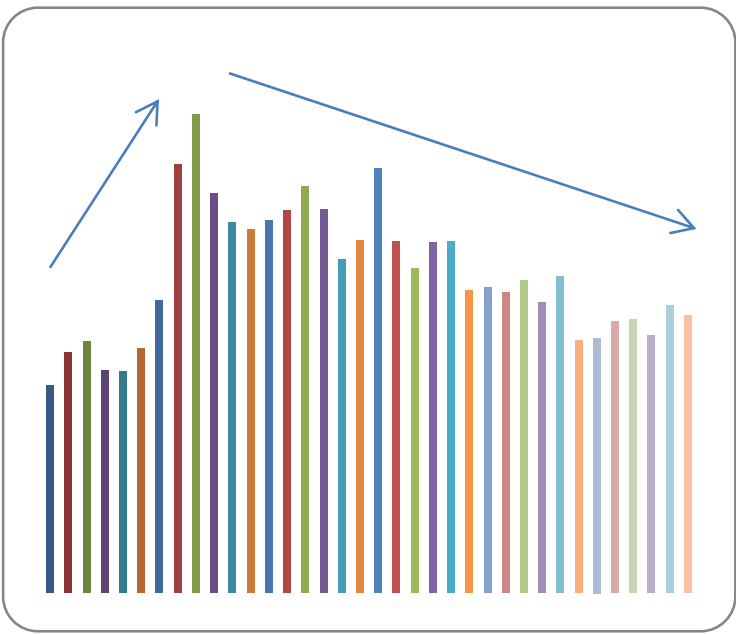

Graph 2 : Investment Ratio

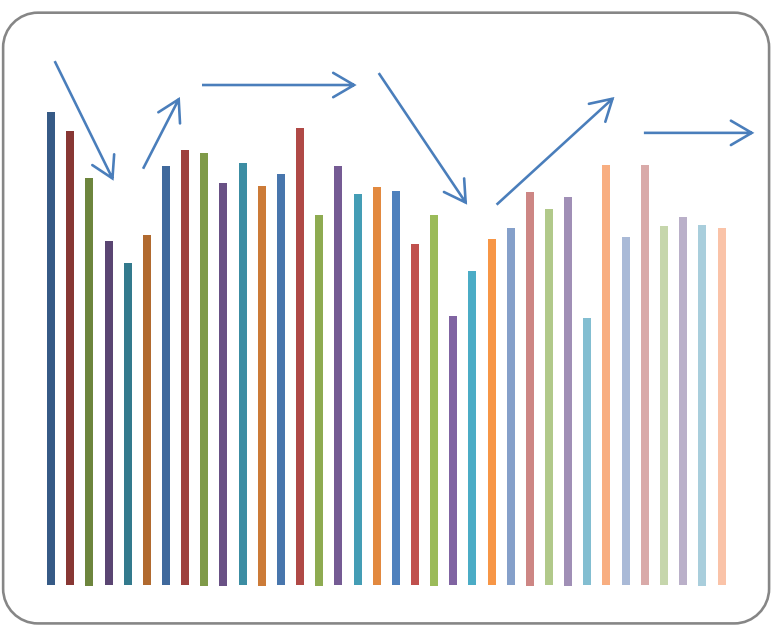

Source: TCMB

If Graph 1 is examined, investment rates increased until 1999. From 1999 onwards, there has been a gradual decrease trend and the lowest investment rate was experienced in 2009 with the effect of 2008 global crisis. Saving rate, which is an important result of low income level, is below the world average in Turkey for the selected period. Investment rates show an independent structure from savings rate. The effects of January $24^{\text {th }}$, that was a revolution in terms of liberalization showed the affects lately because the investment rates tend to fall in the period 1981-1985. The investment ratios, which entered into an increasing tendency in the period of 1986-1993, entered into a decreasing trend with the effect of the April 5 crisis and reached the bottom with the November 2000-February 2001 finance and banking crisis in Turkey. The investment ratios had rising trend again in 2002-2008 and cut sharply after 2008 global crisis. It can be argued that there is an independent relationship between domestic savings and investments in the Turkish economy when the interrelationship between savings and investments is taken into consideration under the assumption of closed economy.

Table 1: Correlation among Variables

\begin{tabular}{ccc}
\hline & INV & SAV \\
\hline INV & 1 & 0.152 \\
SAV & 0.152 & 1 \\
\hline
\end{tabular}

The correlation between variables is positive and can be accepted low at about 0.152 . The main reason for the low correlation between investment and savings rate is the fact that the share of the public sector is quite high in total investment in the Turkish economy. Another explanation is, small investments are financed by domestic savings and large investments by foreign savings in Turkish economy.

Table 2: Descriptive Statistics of the Variables

\begin{tabular}{lccccccc}
\hline & Mean & Maximum & Minimum & $\begin{array}{l}\text { Standart } \\
\text { Deviation }\end{array}$ & Skewness & Kurtosis & $\begin{array}{c}\text { Jarque- } \\
\text { Bera }\end{array}$ \\
\hline INV & 3.056 & 3.278 & 2.703 & 0.130 & -0.853 & 3.873 & $\begin{array}{c}5.525 \\
(0.063)^{*} \\
\text { SAV }\end{array}$ \\
\hline
\end{tabular}

Note: The values within the parenthesis present the probability ratio. ${ }^{* * *} .^{* *}$ and ${ }^{*}$ stands for $\% 1 . \% 5$ and $\% 10$ significance levels respectively. 
The standard deviation value, which is indicative of volatility, is higher for saving rates. Also, the skewness coefficient ${ }^{1}$ that indicates the asymmetry in the probability distribution is considered, both variables are skewed to the left. According to the kurtosis coefficient ${ }^{2}$ indicating the tail distribution of the distribution curve, it is seen that the saving rate is flat and the investment rates are steep. According to the test statistic of the Jarque-Bera test, which has a normal distribution in the null hypothesis, the null hypothesis is accepted at the $5 \%$ significance level and the alternative hypothesis is rejected. According to this, the investment rate is not normally distributed at the level of $10 \%$ for the variable. The savings rate variable shows a normal distribution.

Table 3: ADF(1981) Unit Root Test Results

\begin{tabular}{|c|c|c|c|c|c|}
\hline & Variables & ADF & \multirow{5}{*}{ 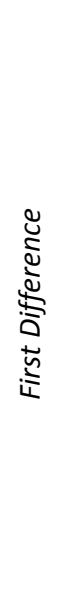 } & Variables & $A D F$ \\
\hline \multirow[b]{2}{*}{ Constant } & INV & $\begin{array}{l}-2.973(1) \\
{[0.047]^{* *}}\end{array}$ & & INV & $\begin{array}{c}-13.277(0) \\
{[0.00]^{* * *}}\end{array}$ \\
\hline & SAV & $\begin{array}{c}-1.856(2) \\
{[0.347]}\end{array}$ & & SAV & $\begin{array}{c}-2.949(4) \\
{[0.051]^{*}}\end{array}$ \\
\hline \multirow[b]{2}{*}{ Constant and Trend } & INV & $\begin{array}{c}-3.006(1) \\
{[0.145]}\end{array}$ & & INV & $\begin{array}{c}-10.169(0) \\
{[0.00]^{* * *}}\end{array}$ \\
\hline & SAV & $\begin{array}{c}-2.331(1) \\
{[0.406]}\end{array}$ & & SAV & $\begin{array}{l}-4.027(4) \\
{[0.018]^{* *}}\end{array}$ \\
\hline
\end{tabular}

Note: ${ }^{* * *} . * *$ and $*$ presents $\% 1 . \% 5$ and $\% 10$ significance levels respectively. The values within parenthesis presents optimal lag lengths according to Schwarz information criteria. The values within brackets presents probability ratios. ADF test: Mac Kinnon (1996) critical values are as follows; For constant model $1 \% .5 \%$ and $10 \%$ significance levels 3.485. $-2.885 .-2.579$ and for constant + trend model $1 \% .5$ $\%$ and10 \% significance level probability values are -3.483 . -2.884 . -2.579 respectively.

For the series to be stationary, the predicted $\tau(\operatorname{tau})$ statistic value of the series should be bigger than the absolute value of MacKinnon (1996) ( $\left|\tau_{h}\right|>\tau_{t}$ ). According to Dickey-Fuller (1981) test results, Investment variable does not have unit root at the $5 \%$ level of significance in the constant model. Saving rate on the other hand has the unit root in the model both models. However, when the first differences of both variables are taken, they are stationary.

Table 4: Co-Integration Test Results

\begin{tabular}{cccc}
\hline Hypothesis & F statistics & \%5 Critical Value & Break Date \\
\hline $\mathrm{H}_{0}$ : No Break & 12.372 & 24.745 & 1999 \\
$\mathrm{H}_{1}$ : One Break & & & - \\
\hline $\mathrm{H}_{0}$ : One Break & 3.349 & 6.699 & \\
$\mathrm{H}_{1}$ : Two Breaks & & & \\
\hline
\end{tabular}

Note: ${ }^{* * *} . * *$ and $*$ values presents $\% 1 . \% 5$ and $\% 10$ significance levels respectively. Trim value is considered 0.15 and max break number is considered 5 . For the $\% 5$ significance level, the critical values are from Bai-Perron (2003).

$$
\begin{aligned}
& { }^{1} \text { For Skewness } S=\alpha_{3}=\left[\begin{array}{ll}
<0 & \text { skewed left } \\
=0 & \text { symmetric } \\
>0 & \text { skwewd rigth }
\end{array}\right] \\
& { }^{2} \text { For Kurtosis } K=\alpha_{4}=\left[\begin{array}{ll}
<3 & \text { flat } \\
=3 & \text { normal } \\
>3 & \text { steep }
\end{array}\right]
\end{aligned}
$$


It is necessary to find the number of co-integration and how many breaks exists. If the calculated F-statistic is greater than $5 \%$ of the critical value, the null hypothesis is rejected and the alternative hypothesis is accepted. Accordingly, the second null hypothesis is accepted that assumes a break in the second level. The date of the break is 1999. The preparation of the 7th Five Year Development Plan in 1996 and the entry into the Customs Union could be considered in the Turkish economy as a reason of the break date of the year 1999. As a result of the Customs Union agreement, the total expenditures in the Turkish economy have increased due to the fact that the European Union countries and customs tariffs and taxes are zero. With the significant developments in politics, the risk perception for the developing countries changed with the 1998 Russian economic crisis in the Asian countries in 1998, affected the Turkish economy.

Table 5: Co-integration Relations Considering the Break Dates

\begin{tabular}{|c|c|c|c|}
\hline & Variables & Coefficient & t statistic (Probability Value) \\
\hline \multicolumn{4}{|l|}{ 1980-1998 Period } \\
\hline & $\mathrm{C}$ & 2.821 & $10.687(0.00)^{* * *}$ \\
\hline & SAV & 0.691 & $-2.980(0.00)^{* * *}$ \\
\hline \multicolumn{4}{|l|}{ 1999-2015 Period } \\
\hline & $\mathrm{C}$ & 4.917 & $7.585(0.00)^{* * *}$ \\
\hline
\end{tabular}

Note: $* * * * *$ and $*$ presents $\% 1 . \% 5$ and $\% 10$ significance levels respectively.

The analysis period covers from 1980 to 2015 . There is a significant break in 1999, so two periods will be considered. Coefficients and constants are statistically significant at the $1 \%$ significance level. In first period that is from 1980 to 1998 , the increase in the saving rates by $1 \%$, the investments increases by $0.103 \%$. In the second period, $1999-2015$, if savings increase $1 \%$, investments increased by $0.691 \%$. If the coefficients considered, the share of the public sector in the total investment is high, and the rate of influence of the domestic savings is lower in the period of 1980-1998. There is no significant relationship between domestic savings and investments in the Turkish economy, in the period that Turkey was almost a closed economy based on the amendment of the law on the protection of the value of Turkish currency in the 1980-1998 period, in particular by the Decree No. 32 of 1989, and which later became integrated with the international markets. Feldstein-Horioka (1980) puzzle does not hold in this period. A significant part of the financing of investments is also covered by domestic savings in the period 1999-2015, when the commercial and financial openness ratio is increasing by integrating to the international markets and close to the open economy assumption. In the study of Feldstein-Horioka (1980), the coefficient was between $0.85-0.95$ for 16 developed country economies, and for Turkey it was about 0.7 in the second period. For the period 1999-2015, it is concluded that Feldstein-Horioka (1980) puzzle is valid for Turkish economy.

\section{CONCLUSION}

Savings are the main source when financing investments; this is an important rule in terms of economics theory and practice. When developed and developing countries examine the growth patterns, the most important determinants of investments are savings, it does not matter if they are going to be borrowed in equity or in the way of borrowing. In this study, the savings-investment relationship in the Turkish economy in 1980-2015 period was examined in the context of Feldstein-Horioka (1980) puzzle. During this period, it was determined that structural breakage occurred in 1999 and there are two periods. In the first period, from 1980 to 1998, the puzzle was not valid and in the second period; 1999-2015 the puzzle was valid. The use of public sector resources in the financing of investments in the 1980-1998 period has increased public sector borrowing requirement and created a crowding-out effect. In the period of 1999-2015, despite the inadequacy of internal savings, the domestic economy and the external demand were high and the Turkish economy recorded significant growth ratios. Saving rates tend to decrease in the vast majority of the 35-year period covered by the analysis. However, investment rates are above the savings rates in the entire analysis period. This situation reveals as one of the main reason of current account deficit in Turkish economy. 


\section{REFERENCES}

Altıntaş, H. ve Taban, S. 2011, "Twin Deficit Problem and Feldstein-Horioka Hypothesis in Turkey: ARDL Approach and Investigation of Causality" International Research Journal of Finance and Economics, 74: 30-45.

Ayaydın ve Baltacı, 2012," Finansal Açıklık, Sermaye Hareketliliği, Tasarruf ve Yatırım İlişkisi: BRıCS Ülkeleri Örneği”, Gazi Üniversitesi Iktisadi ve Idari Bilimler Fakültesi Dergisi, 14/2, ss. 51-74.

Bai, J., \& Perron, P. 2003. “Computation and analysis of multiple structural change models." Journal of applied econometrics, 18(1), 1-22.

Bayoumi, 1990, "Saving-investment correlations: immobile capital, government policy, or endogenous behavior?" Staff PapersInternational Monetary Fund, 360-387

Blanchard ve Giavazzi, 2002. "Current account deficit in the Euro area: The end of the Feldstein-Horioka Puzzle?", Brookings Papers on Economic Activity, 2, ss. 147-186.

Bolatoğlu, N. 2005, "Türkiye'de Yurt içi Yatırım ve Yurt içi Tasarruf Oranları Arasındaki İlişsi" Ekonomik Yaklaşım, 16(56):19-32.

Dickey, David and Wayne Fuller. 1979, "Distribution Of The Estimators For Autoregressive Time Series With A Unit Root", Journal of The American Statistical Association, 74, ss:427- 431.

Dickey, David and Wayne Fuller. 1981, "Likelihood Ratio Statistics For Autoregressive Time Series With A Unit Root" Econometrica, 49, ss:1057-72.

Dooley, Frankel \& Mathieson, 1987, “International capital mobility: What do saving-investment correlations tell us?” Staff PapersInternational Monetary Fund, 503-530

Erataş vd., 2013, "Feldstein-Horioka Bilmecesinin Gelişmiş Ülke Ekonomileri Açısından Değerlendirilmesi: Panel Veri Analizi”, Çankırı Karatekin Üniversitesi Iktisadi ve Idari Bilimler Fakültesi Dergisi, 3(2), ss.18-

Erden, L. 2005, "Structural Adjustment and Domestic Private Saving and Investment Interaction in Turkey: A Cointegration Analysis" Yönetim ve Ekonomi, 12(1):95-103.

Esen, E., Yıldırım, S. ve Kostakoğlu, F. 2012, "Feldstein-Horioka Hipotezinin Türkiye Ekonomisi için Sınanması: ARDL Modeli Uygulaması" Eskişehir Osmangazi Üniversitesi Iktisadi ve Idari Bilimler Fakültesi Dergisi, 7(1):251-267.

Feldstein ve Horioka, 1980, "Domestic saving and international capital flow", The Economic Journal, 90, p.15

Feldstein, 1983, "Domestic Saving and International Capital Movements in The Long Run and The Short Run", European Economic Review, Vol.21, No: 1-2, pp.129-151.

Giannone ve Lenza, 2004. "The Feldsteın-Horıoka Fact", Workıng Paper Series, No 873

Ho, 2002, "The Feldstein-Horioka puzzle revisited", Journal of International Money and Finance, 21, pp:555-564.

Ketenci, 2010, "The Feldstein Horioka Puzzle by Groups of OECD Members: the Panel Approach", MPRA Papers, http://mpra.ub.unimuenchen.de/25848/, ss. 1-25

Kollias vd., 2008, "The Feldstein-Horioka puzzle across EU members:Evidence from the ARDL bounds approach and panel data", International Review of Economics and Finance, 17, pp:380-387

MacKinnon, James. 1996. Numerical Distribution Functions For Unit Root and Cointegration Tests, Journal of Applied Econometrics, 11, ss:601-618.

Obstfeld, 1995, International capital mobility in the '90s. In P. B. Kenen (Ed.), Understanding Interdependence: The Macroeconomics of the Open Economy (pp. 201-261). Princeton: Princeton University Press

Penati \& Dooley, 1984, "Current Account Imbalances and Capital Formation in Industrial Countries",. Staff Papers-International Monetary Fund, 1-24

Wong, 1990, “What do saving-investment relationships tell us about capital mobility?" Journal of International Money and Finance, 9(1), 60-74 (Di lorio \& Fachin, 2007 